\title{
Karl von den Steinen's Ethnographic Research among Indigenous Peoples in Brazil, 1884-1888
}

DoI

http://dx.doi.org/10.11606/ 2179-0892.ra.2019.157033

\author{
Renate Brigitte Viertler \\ Universidade de São Paulo / São Paulo, SP, Brazil \\ $\checkmark$ renatebv@hotmail.com
}

\section{ABSTRACT}

This article analyses and contextualizes the life and work of the German ethnologist Karl von den Steinen (1855-1929), who conducted ethnographic research in Brazil in 1884 and 1887-88. With a solid education in sciences and the humanities, von den Steinen, a physician and psychiatrist, set out to study social institutions, material and spiritual culture among "stone age" tribal societies along the Amazon. Arriving in Brazil in 1884 he studied the Upper Xingu and the Bororo Indians in the Mato Crosso province. In the Upper Xingu area he obtained a rich ethnographic collection and gathered detailed ethnographic data that continue to be useful for modern-day anthropologists. From a theoretical point of view, von den Steinen endorsed the theory of multilineal development proposed by his mentor Adolf Bastian (1826-1905). Despite many difficulties during his stay among the Bororo Indians, he was able to acquire valuable data to be used by those interested in Bororo social institutions and ceremonial life.

\section{KEYWORDS}

Bororo Indians, Upper Xingu Indians, Brazilian Ethnology, History of Anthropology, Indigenous Peoples 
SPECIAL ISSUE | Renate Brigitte Viertler | Karl von den Steinen's Ethnographic

\section{INTRODUCTION}

The European expansion to the East and West Indies during the sixteenth century furthered the discovery of Brazil by Portuguese explorers. The first reports were written by Portuguese, Spanish, Swiss, and Cerman authors; describing the new land and its inhabitants. Europeans arrived on the Brazilian coast in search of new resources, such as pau-brasil (redwood for dying fabrics), tropical plants, spices, precious metals, and stones. The Brazilian indigenous population

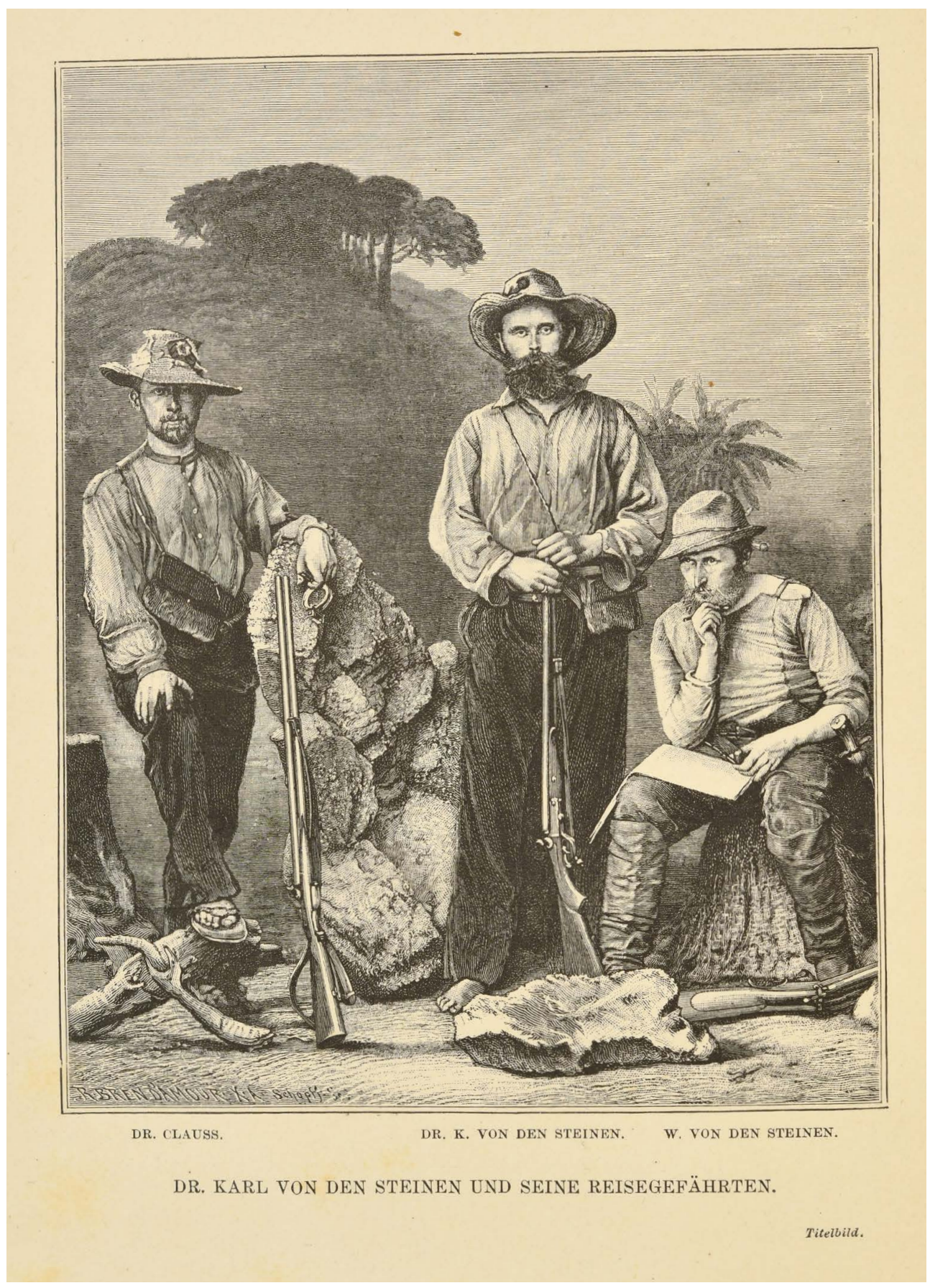

\section{Figure 1}

Karl von den Steinen and his Travel Companions. Left: Dr. Otto Clauss, Center: Dr. Karl von den Steinen, Right: Wilhelm von den Steinen. Wood cut by Richard Bren D'Amour. (Reproduced from: STEINEN, Karl von den, Durch Central Brasilien. Expedition zur Erforschung des Schingú im Jahre 1884. Leipzig, F.A. Brockhaus, 1886, Frontispiece) 
was enslaved, as more labour was required,. Direct contact between indigenous peoples and Europeans led to epidemics, the extinction of many indisgenous societies in the coastal areas and in the Amazon basin, and a dramatic decrease of the Brazilian indigenous population. The increase of gold prospecting and other resources in the Brazilian hinterland, furthered by the Portuguese monarchy, required the establishment of settlements in indigenous territories, leading to interethnic conflicts and changes in the territorial distribution of the indigenous population.

Ethnography and ethnology were developed in the Russian Empire, at the Imperial Academy of Sciences in St. Petersburg; the Cerman universities of Halle, Cöttingen, Leipzig and Jena; and at the court library of Vienna (Austria); during the eighteenth century (Vermeulen, 2015, 2016). In Brazil, ethnology had to wait until the end of the nineteenth century. It was preceded by contributions made during expeditions led by Cerman naturalists such as Alexander von Humboldt (1769-1859), Maximilian Prince zu Wied-Neuwied (1782-1867), Georg Heinrich Langsdorff (1774-1852), Carl Friedrich Philipp von Martius (1794-1868), and Johann Baptist von Spix (1781-1826).

When Karl von den Steinen (1855-1929) undertook his Brazilian researches in 1884 and 1887-88, he developed new standards for ethnographic research. Inspired by the ethnologist Adolf Bastian (1826-1905), and following rigorous methodological steps that had al ready been established in German ethnography, he started what has recently been named as the "beginnings of systematic ethnography in Brazil" (Petschelies, 2018).

At the time of von den Steinen's sojourn in Brazil, a rapid expansion of the economic frontier to the hinterland occurring. The neo-Brazilian population considered the indigenous population occupying too much land; that they were "lazy" and "good to be killed".

In 1884, Dom Pedro II, Emperor of Brazil, helped von den Steinen with the project of exploring the possibilities of navigating the Xingu River, starting from Mato Grosso to Pará and to search for a fluvial connection that might benefit regional economy. The latter plan failed, but the Upper Xingu river basin was opened up to ethnographic research. In the same year, von den Steinen began his first Brazilian expedition to visit this completely isolated and unknown area with the intention of meeting Bakairi, Custenao, Trumai, Manitsauá, Juruna, Nahuquá, Mehinaku laulapiti, Auetö, and Camaiurá Indians. He revisited them during a second expedition in 1887-88 when he also met Pareci Indians in Cuiabá and stayed among the Bororo of the Teresa Cristina colony at the São Lourenço River. It should be noted that these two tribes were already engaged in direct contact with the neo-Brazilian population of Mato Grosso province.
1 The extermination of the Indian population intensified in such a way that an Indian Protection Service was founded in 1910 with the aim of civilizing Brazilian Indians by transforming them into good working citizens. 


\section{LIFE AND WORK}

Born in Mühlheim as the son of a physician, Karl von den Steinen attended school in Düsseldorf and concluded his school days at the early age of 16. Despite his humanistic background, he studied medicine at the universities of Zurich, Bonn, and Strasbourg, at the Physiological Institute where he obtained his PhD in 1875. After specializing in psychiatry at the University of Vienna in 1878-79, he worked as a medical assistant at the famous Charité hospital in Berlin (Thieme, 1993: 41).

At that time, Berlin was an important center of innovations in science and the arts. After the fall of Napoleon Bonaparte and the Restoration policies, the city had been chosen as the capital of the Prussian monarchy; after the Cerman unification of 1870-71, it served as the capital of the Second Empire. Its university, the Friedrich Wilhelm Universität, later called the Humboldt Universität, counted among its staff the pathologist and physical anthropologist Rudolf Virchow (1821-1902) and the physician and ethnologist Adolf Bastian (1826-1905), director of the Königliches Museum für Völkerkunde in Berlin who made nine research and acquisition trips around the world.

In 1879, Karl von den Steinen began travelling around the world. From Bremen he sailed to New York, Cuba, Mexico, the United States, Polynesia, Java, China, Japan, India, and Egypt, to study various treatments of mental diseases. In Polynesia, on Honolulu, he met Bastian, the well-known traveller, who suggested for him to engage in ethnological researches and collect ethnographic material.

It was a time of great innovations and experiments in psychology. Apart from studies of the "unconscious," psychophysics, and the Völkerpsychologie (psychology of peoples) of Moritz Lazarus (1824-1903) and later Wilhelm Wundt (1892-1920), there was the work of the psycholinguist Johann Friedrich Herbart (1776-1841). Herbart considered that psychological analysis is not limited to the individual but also encompasses society, a view adopted by the ethnologist Bastian.

Trained as a physician and skilled in psychiatry and neurology, Adolf Bastian developed modern and surprising reflections about phenomena such as possession, exorcism, and the psychological contagion associated to religious life and mythology of Naturvölker ("peoples living in nature"), relating them to manifestations observed in psychiatric clinics. Bastian endorsed the principle of the psychic unity of humankind by proposing the concept of "elementary ideas", universals that can be found among all human societies.

Returning from Southern Ceorgia in 1883, von den Steinen passed Montevideo (Thieme, 1993: 42) and began planning an ethnological expedition. Interested in "stone age people" living in Central South America, he first planned to visit the Chiriguano of the western Chaco. Ultimately, he explored the Upper Xingu, an uncharted river of interest to Brazilian provincial authorities since, if navigable, it would allow access to the international market in Amazonia (Thieme, 1993: 49). 
Encouraged and materially assisted by the Brazilian emperor Dom Pedro II, Karl von den Steinen, Wilhelm von den Steinen a designer, a designer and draughtsman, and Otto Claus, a geographer and astronomer, started to explore the province of Mato Crosso for the first time in 1884. They departed from Cuiabá and reached the Upper Xingu area. During a second expedition to the same area, carried out in 1887-88, Karl von den Steinen and his cousin Wilhelm were accompanied by Paul Ehrenreich, an ethnologist, and Peter Vogel, a geographer (Schaden, 1993: 111).

After his two expeditions in Brazil,

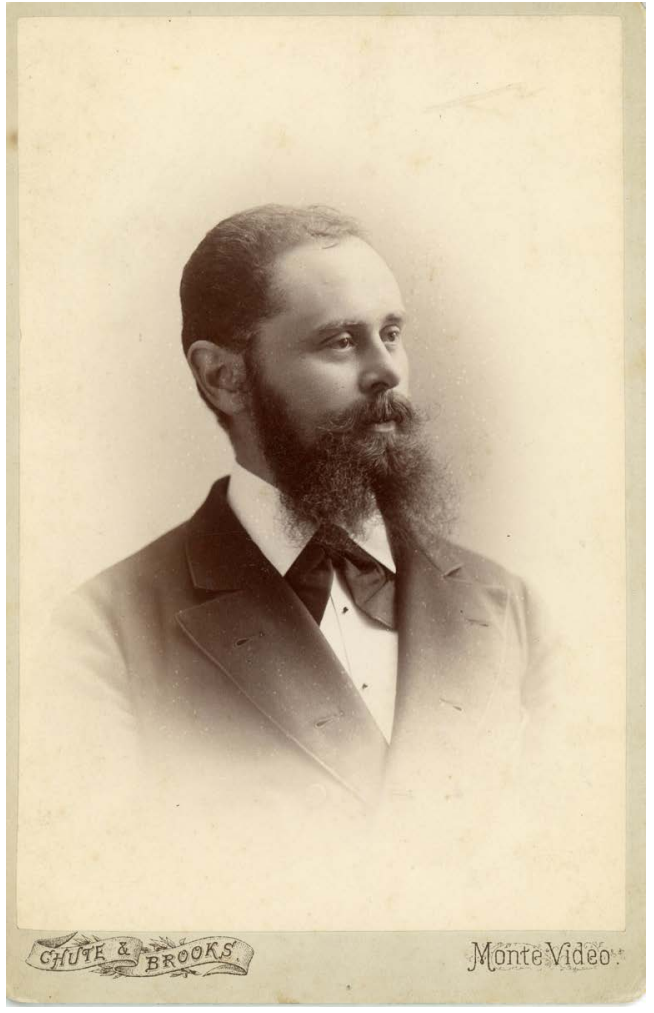
Figure 2

Karl von den Steinen posing in Montevideo, 1883. Photograph by Chute \& Brooks. (Courtesy: Reimar Schefold, Amsterdam, The Netherlands, Family Archive)

Karl von den Steinen went to the Marquesas Islands and to Polynesia in order to study the material culture, plastic arts, and tattoos of their inhabitants and to obtain new ethnographic collections (Thieme 1993: 4) and returned to Cermany in 1898

In 1889, Karl von den Steinen married Rosa Eleonore Herzfeld and they went to live in Berlin-Steglitz, having eight children. It was also in 1889 that he presented his habilitation thesis to the University of Berlin. Entitled Erfahrungen zur Entwicklungsgeschichte des Völkergedankens (Experiences regarding the Developmental History of the Thinking of Peoples), this study connected his observations to Bastian's cultural theories. Subsequently, he started lecturing at the University of Berlin. After a year he obtained a chair in ethnology at the University of Marburg where he intended to elaborate his ethnographic data. However, he remained in Marburg for only two years and returned to Berlin in 1893 to resume his activities at the university and at the Museum of Ethnology (Thieme, 1993: 83).

There are three books relating to von den Steinen's two expeditions in Brazil, which are Durch Central Brasilien (Through Central Brazil), 1886; Unter Naturvölkern Zentral Brasiliens (Among Peoples of Nature in Central Brazil), 1894; and Die Bakairi-Sprache: Mit Beiträgen zu einer Lautlehre der karaibischen Grundsprache (The Bakairi Language: With Contributions to a Phonetics of the Carib Basic Language), 1892.

At the funeral service of Adolf Bastian in 1905, Karl von den Steinen read his mentor's obituary in which he praised him and summarized his theoretical ideas. After retiring from official duties in 1906, von den Steinen went on editing the Zeitschrift für Ethnologie (Ethnological Journal) and the review Das Ausland (The 
Exterior) until 1911. He continued to develop activities at the Deutsche Gesellschaft für Anthropologie, Ethnologie und Urgeschichte (Cerman Society of Anthropology, Ethnology and Prehistory) founded by Virchow and Bastian in 1869, until 1928.

Von den Steinen had become friends with the Swedish prehistorian and ethnologist Erland Nordenskiöld (1877-1932) from the Etnografiska Museum of Göteborg; they correponded about subjects such as spinning techniques of the Bororo and Bakairi Indians, Polynesian art, palisades or wooden drums of the Kamayurá and the Bakairi Indians (Thieme, 1993: 93).

Apart from ethnographic subjects, von den Steinen and Nordenskiöld exchanged personal information about his deceased son, poverty, or disgust against the conditions of the Versailles peace treaty imposed on Cermany at the end of World War I. ${ }^{2}$ With rising inflation after the first World War the family was obliged to move to a more modest home in Berlin-Wilmersdorf. Von den Steinen could no longer afford a secretary and gave up his library in exchange for food. In 1928 von den Steinen invited Nordenskiöld to join him at his new residence in Kronberg (Taunus) but he died a short time after, on 4 November 1929 (Thieme, 1993: 101).

\section{THEORETICAL PRINCIPLES}

In Cermany, ethnologists believed that the best way of obtaining solid knowledge about phenomena was to start by describing them in the most detailed way possible. This principle had been introduced by historians and philosophers in the eighteenth century and became a tradition in Cermany that was followed by nineteenth-century ethnologists such as Theodor Waitz (1821-1864), Gustav Klemm (1802-1867), Friedrich Ratzel (1844-1904), and Adolf Bastian. This was criticized as "excessive" by Paul Mercier (História da Antropologia. Rio de Janeiro, Livraria Eldorado Tijuca, 1974) and other English- and French-speaking ethnologists. "Cerman empiricism" was a response to the general lack of trustworthy ethnological data confirmed by Anthropological Associations at that time. Differing from British and French ethnology, Cerman ethnology or Völkerkunde stressed the importance of linguistic data and material culture. Each artifact found its place in an ethnographic collection that, by means of esthetical patterns, codified cultural values and ideas pertaining to human social life.

While English-and French-speaking ethnologists proposed a universal largescale process of socio-cultural evolution, von den Steinen was influenced by the theoretical approach of Bastian, who viewed regional socio-cultural developments as activated by the interplay of the human psyche: Elementargedanken (elementary ideas), based on the psychological unity of human beings despite their physical differences; geographische Provinzen (geographical provinces) exerting pressures on the regional habitat; and historical relations between individuals or groups pertain-
2 Besides all his problems Karl von den Steinen also suffered from cataract in both eyes. 
ing to different geographical provinces. The conjunction of these three dimensions may or may not have stimulated the growth of human cultures he defined as Völkergedanken (thoughts of peoples), a concept that corresponds to the concept of culture, introduced by Custav Klemm in the middle of the nineteenth century and endorsed by Edward Burnett Tylor (1832-1917) from 1871 onwards.

From a methodological point of view, aside from bibliographical research and direct observations in the field, von den Steinen also used iconographic information from the designs of Amadeo Adriano Taunay and Hercules Florence, former members of the Langsdorff expedition. Since human "language" represents an indispensable tool for understanding human "thinking," von den Steinen conducted extensive linguistic research with the help of his main informer, Antonio, chief of the Bakairi Indians. In terms of material culture, he obtained an ethnographic collection of artifacts that, according to his mentor Bastian, may be conceived as a creative fusion between "ideas" and raw materials from a specific habitat. Without the help of photographic resources human types, houses, ornaments, body paintings, and scenes of social activities had to be registered by means of drawings made by

\section{Figure 3}

Antonio, the Bakairí Indian from Paranatinga, who was Karl von den Steinen's main informant during his stay in the upper Xingu area. Photograph by Paul Ehrenreich, October 1887. (Courtesy: Ethnologisches Museum, Staatliche Museen zu Berlin, Germany, No. VIII E NIs 108). Reproduced by Karl von den Steinen in his book Die BakaïríSprache (1892). 
Karl's cousin Wilhelm von den Steinen. Karl von den Steinen, who also made drawings, offered iron tools in exchange for verbal informations and artifacts.

\section{IN THE UPPER XINGU AREA}

Following the German tradition, von den Steinen tried to collect the largest possible number of ethnographic data relating to the material and spiritual culture of the Upper Xingu Indians. Basing himself on the comparative linguistics that had been developed by Wilhelm von Humboldt (1767-1835), von den Steinen started to employ language as an important criterion for ethnographic classification. He regarded Upper Xingu society as an isolated group of representatives from four linguistic families of Brazilian Indians - Carib, Aruak, Tupi, and Cê-each represented by one or more villages.

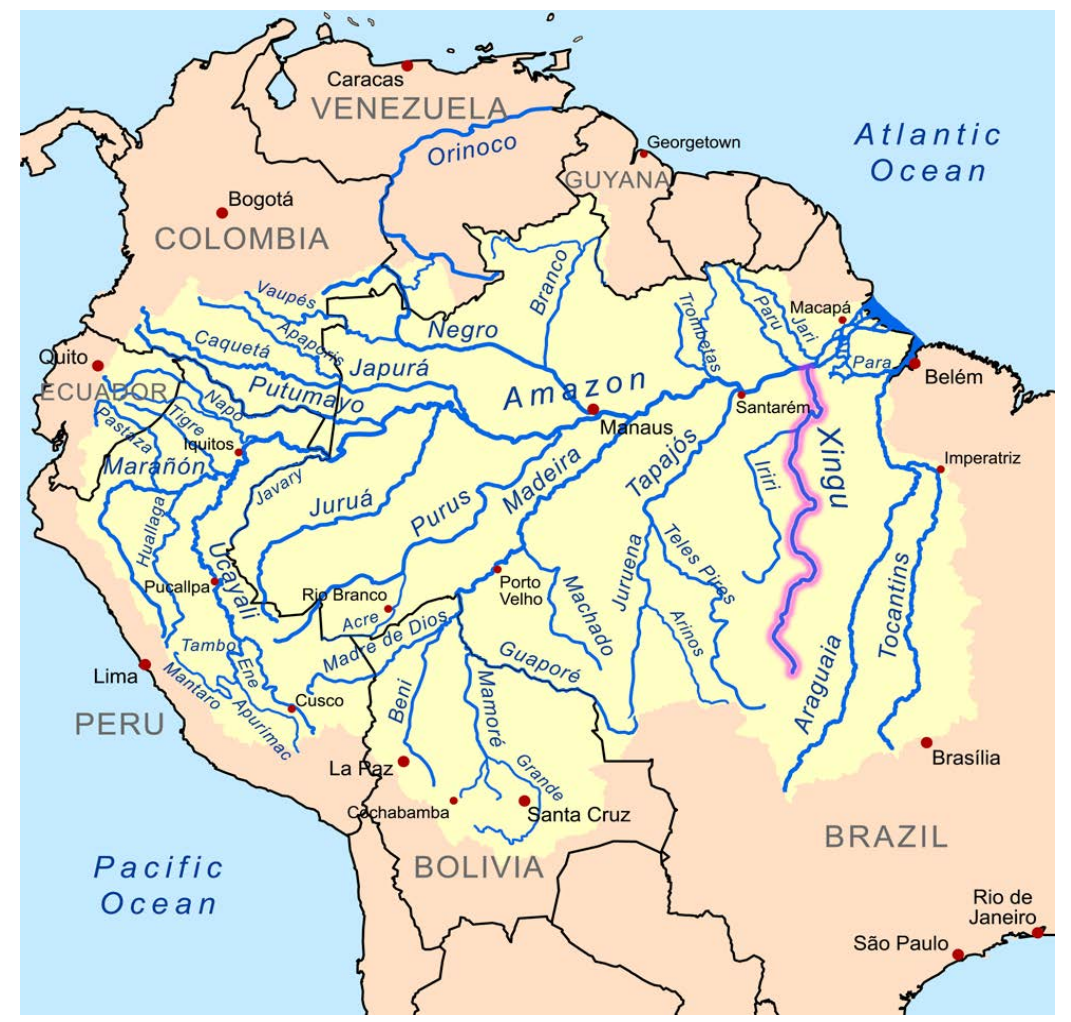

Although Martius saw indigenous people as inferior or degenerated, a view that was unacceptable to von den Steinen (Schaden, 1977: 4 apud Thieme, 1993: 46), he had proposed a linguistic classification that was useful for both von den Steinen's and Paul Ehrenreich's linguistic classification, proposed almost one century later (Baldus, 1954: 12-13). Von den Steinen redefined Martius's linguistic classification by means of the comparison of linguistic elements that he correlated with cultural and etno-historical data relating to migrations through the South-American continent. He classified the Bakairi language as belonging to the Carib linguistic family and proposed that there had been Carib migrations starting from the region of the Upper Tapajós and the Xingu rivers. He did not agree with Alexander von Humboldt, who had suggested that Carib migrations originated from northern South America or the Antilles (Schaden, 1993: 58-59). Von den Steinen's hypothesis, based on infering migrations, routes and origins departing from linguistic data, was criticized by Cerhard Baer (1934-2017); although Egon Schaden (1913-1991) felt that nobody was able to entirely refute it (Schaden, 1956: 123).

Apart from establishing that the language spoken in the various Bakairi villages belonged to the Carib linguistic family, von den Steinen also considered 
the Mehinaku and laualapiti part of the $(\mathrm{Nu})$ aruaque linguistic family, the Aueté and Kamayurá part of the Tupi family, the Araueté linguistically representing a mixture of Tupi and ( $\mathrm{Nu}$ )aruaque, and the Trumai belonging to an isolated linguistic family. His linguistic research, required by Cerman ethnography, was important because linguistic knowledge represented a vital tool for understanding the spiritual and material culture of Upper Xingu Indians.

Despite their linguistic differences and some material specialties related to intertribal trade, Upper Xingu Indians showed many uniformities such as: the slash-and-burn cultivation of manioc and other crops, the preparation of food, stone axes, teeth-and shell-tools, fishing nets, the lay-out of the villages, architecture, cotton hammocks, big round and small ceramic pots, wooden zoomorphic stools, shell necklaces, feather ornaments, uluri (women's pubic attire), gourds, the use of tobacco, body paintings, musical instruments, weapons and social institutions. According to von den Steinen, the Upper-Xingu cultural traits and patterns seemed to have originated through diffusion due to frequent intertribal visits during funerals and festivities that had stimulated exchanges (von den Steinen, 1940: 428-429). Although he did not yet employ the concept of "intertribal acculturation," von den Steinen assumed that this "leveling" process (or cultural diffusion) in the Upper Xingu area was still occuring (op.cit.).

As a psychiatrist, von den Steinen showed a tendency to discuss problems relating to the Upper Xingu in psychological terms and he intended to describe the peculiarity of the Indians' mentality. Despite their horticultural activities, von den Steinen argued that they reacted as hunting and gathering societies (Schaden, 1993: 115-116) and belonged to the "stone age" in view of their rudimental technology, such as stone axes, and the lack of generic concepts or higher abstractions that characterize human societies of a higher cultural level. The cultural homogeneity of the Upper Xingu had been explained as the outcome of a history of peaceful alliances among Indian populations of different cultural origins furthering a process of intertribal acculturation. According to Schaden,

One of the most intriguing aspects of the problem continues to be the existence of distinct manifestations material and non-material cultural elements of originally heterogenous ways of life. The innovations are marked in such a way that each tribe continues to maintain its language and does not give up certain cultural specifics (Schaden, 1993: 116).

Despite the cultural uniformity of the area as the result of past and on-going regional cultural-historical processes, von den Steinen found that there was a certain unevennes among the tribes showing that the levelling (i.e., acculturation) was still occurring and allowed for culture-historical inferences and the 
recognition of regional processes of cultural development. Hence, he proposed an interpretation of cultural developments based upon a multilineal approach.

Besides the cultural diffusion furthered by frequent intertribal relationships, von den Steinen also intended to explain the origins of certain cultural traits in terms of independent evolution, a process of cultural growth by means of new ideas or "thoughts" based on psychological associations. Studying the data he had collected on spiritual and material culture, he concluded that in the Upper Xingu area, there was an ongoing evolutionary process from "inferior" to "superior," from "practical" to "aesthetic" - exemplified by the Indian practice of "rubbing their body with urucu to protect their skin" evolving to "urucu body paintings" as an esthetic expression; and from "concrete" to "abstract" - exemplified by conceiving a fish in the bottom of a fishing-net as having inspired the merexu or "decorative motive" painted on artifacts, such as masks, pots and stools, that originated from certain visual aspects of animal species in the area. Von den Steinen tried to formulate the intrinsic logic of the "origins" of concrete cultural manifestations in terms of "thoughts growing out of combinations and interactions among sensations, images, and ideas," a theory formulated by the psycholinguist Herbart, who had also inspired Bastian's theory of the Völkergedanken (Viertler, 2018: 206).

According to Herbert Baldus, "Karl von den Steinen's discoveries and subsequent studies furnished material of perennial value to the cultural history of the continent. They completed and modified the ethnographic map and familiarized us with Indian life as no other previous study, and few other subsequent ones, have done" (Baldus, 1954: 30). However, ethnographers of the Upper Xingu, such as Paul Ehrenreich, Herrmann Meyer, Fritz Krause, Mark Münzel and Rolf Krusche among others, realized that their rapid journey through the area would entail negative consequences. After the German visitors had left, several flu epidemics reduced the indigenous population in the area. In addition, during his fieldwork, von den Steinen himself had been responsible for the distribution of large quantities of iron axes and knives that, despite being eagerly desired by the indigenous peoples, caused the rapid decay of traditional techniques, while migrations and changes in the spatial distribution of indigenous communities increased the social pressures on Brazilian regional society.

\section{AMONG THE BORORO OF THE SÃO LOURENÇO RIVER}

While the Upper Xingu area was still isolated at the end of the nineteenth century, the Bororo Indians had been exposed to intense social pressures since the early eighteenth century, at a time when some inhabitants of São Paulo, called bandeirantes, formed armed expeditions guided by indigenous slaves and left the coastal areas for Mato Crosso and Goiás in search of Indians, precious met- 
als, and precious stones. These expeditions, called bandeiras, were controlled by the Portuguese crown with the purpose of increasing its political hegemony over the Brazilian territory against Spanish invasions.

The first neo-Brazilian settlements of Mato Crosso were established in Bororo Indian's territories who retaliated. During these interethnic conflicts some Bororo were reduced to slavery and obliged to work in the gold mines or on the plantations in Mato Crosso and São Paulo. Others were forced to become soldiers of the bandeirantes, such as Antonio Pires de Campos, who fought against the Kaiapó, the Akroá, and the Xakriabá Indians apart from the Paiaguá indigenous communities, who were attacking the newcomers and hindered regional commerce.

From 1725 to 1727, Mato Grosso province suffered a severe food supply crisis while slaves escaped and miners left Cuiabá in search of new gold repositories. Around 1750, escaping from famine and epidemics, several groups of Bororo crossed the Brazilian border and settled in Bolivian territories, creating the Bororo Ocidentais (western Bororo). They engaged in hostilities against the neo-Brazilians, stealing iron tools but were later subdued and obliged to work in exchange for metal tools, clothes, and liquor.

Meanwhile, the Bororo Orientais (eastern Bororo) continued their hostilities against neo-Brazilians. Between 1771 and 1775 large farms were established along the Cuiabá River and the expanding economic frontier invaded and occupied further Bororo territories while their traditional owners retired to isolated areas near the São Lourenço River.

During the nineteenth century the Bororo of the São Lourenço river continued to all cruelties perpetrated by the "civilized" in a never-ending cycle of hostilities. It was only in 1886 that the president of Mato Crosso province finally ordered the pacification of the Bororo living on the margins of the São Lourenço River. This difficult task had to be accomplished by soldiers established in two colonies along the São Lourenço River.

Since the eighteenth century, suspicious and afraid of the "fierce Bororo," neo-Brazilians offered them liquor obtained from many distilleries established around the lower Cuiabá River. This practice was intensified after the Bororo pacification of 1886 and reinforced by regional politicians, who used to enter Bororo Indian reservations before elections, and by the Bororo themselves. ${ }^{3}$

In 1888, leaving the peaceful and bucolic atmosphere of the Upper Xingu, Karl von den Steinen went to visit the Bororo living in the Teresa Cristina colony who received systematic liquor distributions from the colony administrators. The aim was to control them and keep them inside the colony in order to prevent Bororo hunting and gathering expeditions that might get in the way of the Brazilian economic expansion (Viertler, 1993: 185). 


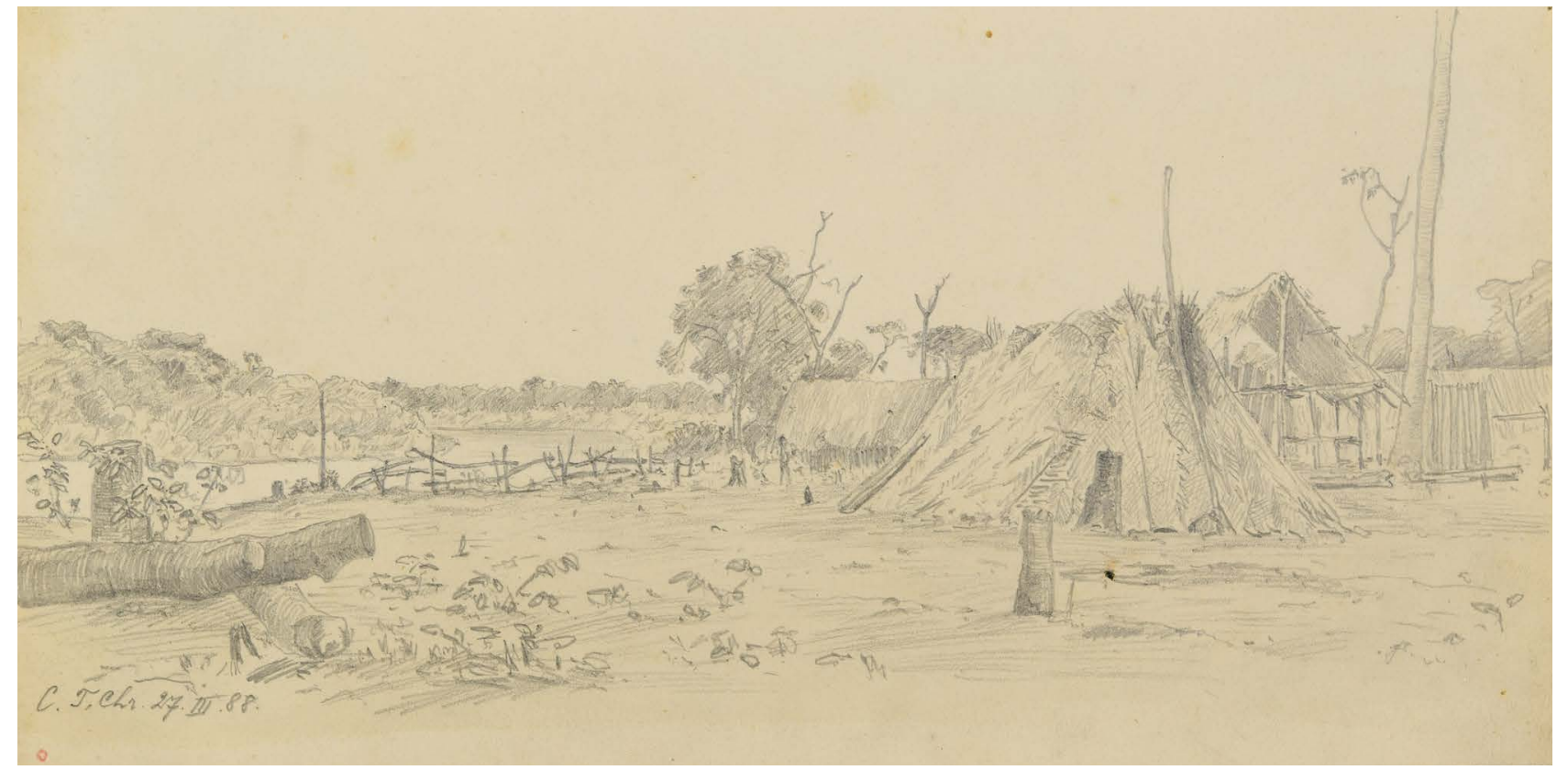

Soon after his arrival, the two hundred Bororo Indians living in promiscuity with more than fifty neo-Brazilian soldiers and a few corrupt military administrators in concubinage with Indian women shocked Von den Steinen. Afraid of the Bororo (who had been pacified only two years before), the administrators of the colony offered them gifts such as clothes, food, and sugar-cane liquor without any work or pay. This situation caused indignation among the soldiers who were obliged to pay for everything they needed. Besides, they also had to work hard in fields that were systematically plundered by the Bororo. Von den Steinen explained this plundering in terms of the Bororo's stage of socio-cultural evolution since, as hunters and gatherers, they seemed to lack any knowledge of horticulture. However, during his stay in Teresa Cristina, he was told about a Bororo village downstream that was producing various species of gourds, corn, tobacco, and cotton yet von den Steinen still classified the Bororo as being hunters and gathers. Later research showed that the Bororo did have horticultural knowledge at the time of von den Steinen's visit and seem to have refused to "work" for neo-Brazilians who they considered as subordinates and therefore entitled to work for the Bororo. This interpretation may explain why eventual gifts of iron tools offered by von den Steinen would not be well accepted by the Bororo of Teresa Cristina.

Based on ethnographic and iconographic material, von den Steinen concluded that despite some differences, the Bororo of the São Lourenço river belonged to the same tribe as the Bororo da Campanha and the Bororo Cabaçais near the Paraguai river. He rejected Martius's hypothesis that the Bororo were the result of a colluvies gentium, a cluster of people of different origins. According to von den Steinen, the division of the Bororo into Occidental and Oriental may be seen as the result of diffusion through migrations of various Bororo groups originat- gs in the Colônia Teresa Cristina. Drawing made by Wilhelm von den Steinen on March 27, 1888. (Courtesy: GRASSI Museum für Völkerkunde zu Leipzig, Staatliche Kunstsammlungen Dresden, Germany) 


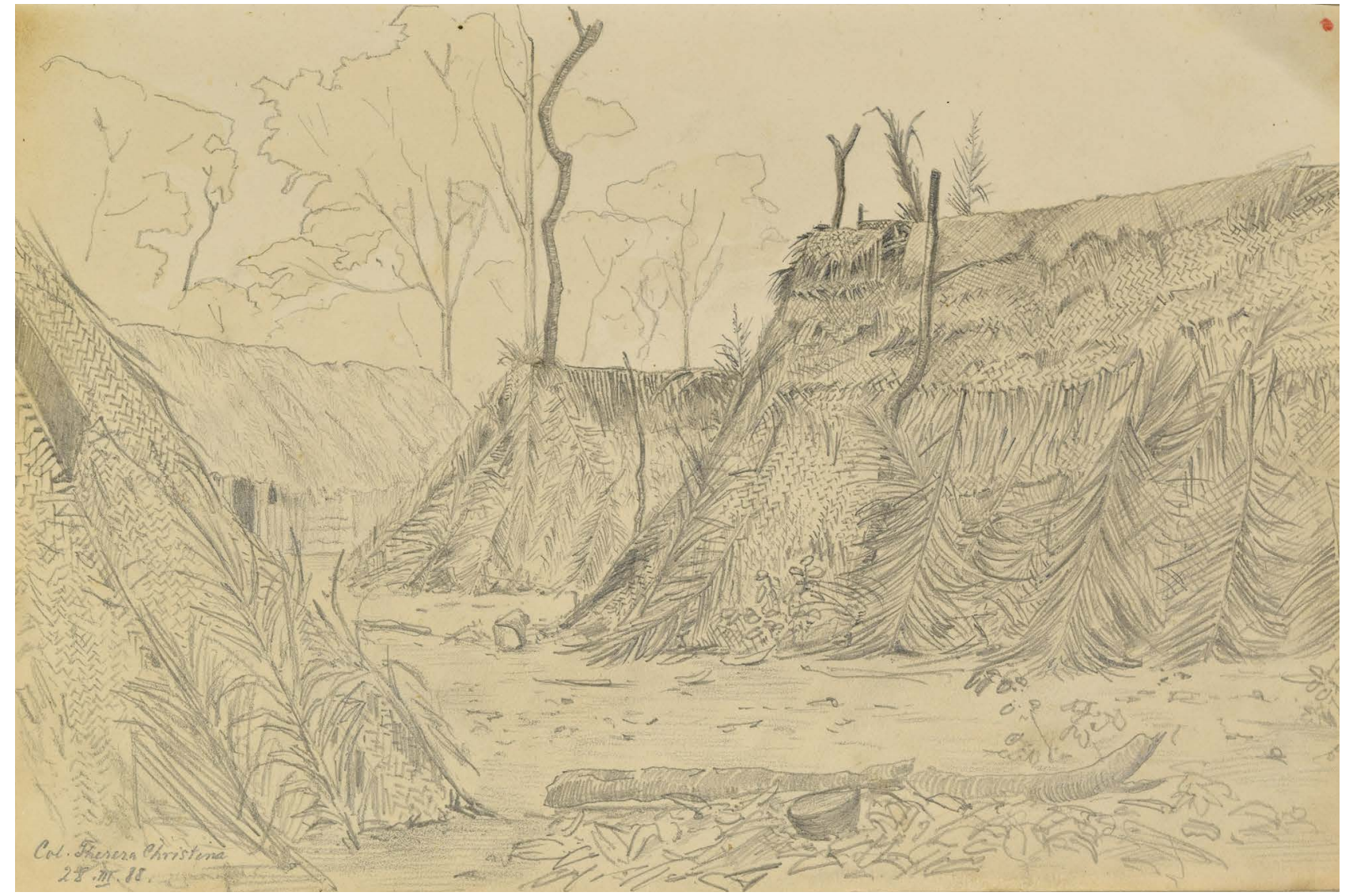

ing from the area of the lower São Lourenço River (von den Steinen, 1940: 568).

Still marveled by his experience in the Upper Xingu, von den Steinen was disgusted by the humiliating conditions in which the Bororo lived in Teresa Cristina. He could not help but opening his heart by means of a sarcastic description of the drunk Diapocuri. He was frustrated by the impossibility of doing systematic research of the Bororo language, which he considered pertaining to Dwellings in the Colônia Teresa Cristina. Drawing made by Wilhelm von den Steinen on March 27, 1888. (Courtesy: GRASSI Museum für Völkerkunde zu Leipzig, Staatliche Kunstsammlungen Dresden, Cermany) an unknown linguistic family (later identified as the Macro-Cê or Otuké family). However, despite all difficulties, he obtained precious information about social institutions and funerary ceremonies.

In Teresa Cristina, despite the daily turmoil caused by drunken Bororo and a funeral ceremony - usually a time of much drinking (traditionally of fermented palm tree sap) and social tensions - von den Steinen was able to obtain rich ethnographic data about many aspects of Bororo material and spiritual culture, confirmed by later ethnological research. He considered Bororo social organization of the utmost ethnological interest because it displays unknown social institutions: (1) the institution of the "women of the men's house"; (2) the "blessing ceremonies" over certain animal and vegetal species before they are consumed; and (3) the "representation of the deceased's souls." Von den Steinen explicitly considered that the first two institutions were linked to food shortage and, as was stated later, the third institution, being associated with hunting and fishing expeditions, was 
also linked to periodical food distributions in the village (Viertler, 1991).

According to von den Steinen, there was a clear social division between older married men living in the houses of their wives and youth, and bachelors living in a central men's house (baito). The bachelors only had sexual access to a small number of young unmarried women (aredo baito), who were forbidden to procreate. After intercourse, the bachelor was obliged to offer ornaments or arrows to the older male relative of the woman he had had intercourse with. Von den Steinen interpreted this institution as a way of restricting demographic growth, of limiting the population size and, therefore, as a social strategy to reduce the need of food (Thieme, 1993: 79) in a very harsh environment. This idea was later confirmed by ecologists who characterized the Bororo territories in Central Brazil as a habitat of strong seasonal resources fluctuations.

Von den Steinen studied the rigorous patterns of food distribution. There were taboos and rules for consuming certain animal and vegetal species only after they had been ceremonially blessed and divided by a bari, a shaman who, by means of his spirits, punishes anyone who breaks the rules with death. In contrast to the chaotic food distributions organized by the administrators of the colony, food was traditionally prepared and distributed in an orderly and peaceful manner. This was mainly, as was found out later, during collective meals honouring the souls of the deceased.

The Bororo men's house was also an artisanal space for producing beautiful feather ornaments, spinning cotton, or singing before hunting and fishing expeditions required by ceremonial life. Von den Steinen did not explicitly mention the institution of the "representation of the deceased" by a Bororo hunter designed as a "new soul" (aroe maiwu), who was tasked to revenge the deceased by hunting a jaguar. Despite aversions and frustrations, von den Steinen made such an accurate description of this particular character that we may identify the drunk Diapocuri as one of those ritual hunters who, painted in black and wearing a string made from human hair, had been chosen as the "representative" of one of the two deceased Bororo whose funeral was celebrated at the time of his visit. Later ethnologists have supported that the "representative of the deceased", besides hunting, offering trophies of the dead animal to the mourners and dancing during the funeral ceremonies they were also obliged to provide food for the mourning family as long as they lived; hence, another original social strategy for guaranteeing food to completely deprived members of the village.

In the middle of the turmoil in Teresa Cristina, von den Steinen successfully carried out a very difficult line of research. ${ }^{4}$ Bororo ceremonial chiefs demand total obedience of their orders, an inversion of the political hierarchy of everyday life that may obstruct ethnological research. However, despite all these difficulties, von den Steinen managed to follow Bororo funeral etiquete. He accurately

4 Present-day ethnologists feel it is also difficult, sometimes even impossible, to continue their research, mainly with Bororo Indians directly involved in funerals, a time of much drinking and latent hostilities against foreigners. 
described the mourners's weepings, collective huntings, funerary dances, hunting chants, and the incineration of the deceased's property; a practice he interpreted as a way of eliminating the accumulation of material property. With this interpretation, von den Steinen foreshadowed later economic anthropologists such as Ceorge M. Forster who formulated the law of "the limited good" among non-capitalist societies.

At the end of the funeral cycle, after much collective singing and dancing, the Bororo performed - and still do - the aije ceremony forbidden to non-initiated women and children. The aije-doge or bull-roarers ceremony is associated with the washing of the rotten corpse, a gruesome task done by the representative of the deceased's soul. Von den Steinen described the bull-roarers being whirled in circles and buzzing in the middle of the village, frightening women and children locked in their houses. During such a tense ceremony he managed to register the bull-roarers's decorative motives - bands, circles and squares - which he interpreted as having originated from the vision of the deceased's bones, skulls, and the square funerary baskets that had to be blessed, painted, and feathered (von den Steinen, 1940: 634). Therefore, as proposed for the Upper Xingu, Karl von den Steinen explained the origins of Bororo decorative motives - bands, circles and squares - by ideas departing from concrete visual experiences.

Ethnographically comparing the Upper Xingu Indians with the Bororo of the São Lourenço, von den Steinen suggested that the latter being at a less advanced cultural stage, saw the bull-roarers as a way of communicating with the dead. In contraposition, the Upper Xingu Indians, at a more advanced stage, used them as toys and in dances. However, according to him, the variability of their meaning in the context of different tribes required careful analysis in each case (von den Steinen, 1940: 633).

Von den Steinen, always interested in establishing the "origins" of cultural traits and patterns, also interpreted Bororo women's belts having broad grey stripes originating from the practice of carrying heavy baskets on their back during collecting activities - the stripes functioning to support the basket and at the same time to protect the skin. He also interpreted the custom of decorating whole parts of the human body with feathers as a form of medicine (Thieme, 1993: 81).

Apart from details relating to the institutional aspects and material culture of Bororo Indians, von den Steinen also discovered many aspects of their spiritual life which he described by means of "thoughts." These included, "the equivalence of men and animals," or "if a Bororo kills an animal its' spirit will kill the Bororo," or "funerary hunting and fishing as expeditions represent a way of communicating with the dead" - exemplifying Bororo ideas composing a particular Weltanschauung. In the twentieth century this procedure was also employed by American configurationists from the culture and personality school. 
He did not frame his ethnographic data in terms of social morphology concepts such as "moieties," "clans," or "kinship," sociological concepts later employed by the Salesian missionaries. In this respect he followed the principle of Herbart that sociological and psychological aspects cannot be separated. Accordingly, he did not see social relations as an autonomous aspect of human social life that can be detached from spiritual and material cultural data. However, he succeeded in distinguishing the social function of the bari, a shaman connecting to the spirits of animals and plants, from that of the aroe etawara are, a shaman connecting to the souls of the deceased.

The numerous and accurate ethnographic data obtained by Karl von den Steinen in the short time he spent among the Bororo, attests to his sensitivity as a social researcher working in the Cerman tradition of obtaining the most reliable and best ethnographic information. His ethnographic data relating to the Bororo give priority to social institutional and ceremonial aspects, while those obtained in the Upper Xingu river basin reveal an emphasis on material culture and linguistic data. In the Upper Xingu area he was able to develop linguistic research and to obtain a rich collection of artifacts (approximately 1.322 items) now held at the Ethnological Museum in Berlin. According to Cünther Hartmann (1993), only 349 artifacts were obtained from the Bororo in Teresa Cristina. We may consider that, at the time of von den Steinen's visit, many epidemics were already hitting the Bororo, requiring more funerals and incinerations of traditional artifacts that had belonged to the deceased. Besides, the growing shortage of raw material caused by the loss of tribal territories and the negative ecological impact of the neo-Brazilian expansion made it more difficult, if not impossible, to produce certain traditional artifacts. ${ }^{5}$

\section{CONCLUSION}

The careful compilation of ethnographic data is one of the main characteristics of the ethnographic tradition created by Cerman ethnographers working in Russia and elsewhere during the eighteenth and nineteenth centuries. Differing from British and French ethnology, German Völkerkunde stressed the importance of linguistic data and material culture, as did von den Steinen. Opening the way for Brazilian ethnology (Petschelies, 2018: 544), he compiled accurate ethnographic data that continue to be valuable for new research.

According to Baldus (1954) the two Xingu expeditions of Karl von den Steinen were the most important events in nineteenth-century Brazilian ethnology and inspired new research for Cerman ethnographers. These included Paul Ehrenreich (1855-1914), who had done independent research in Brazil in 1884, who accompanied von den Steinen during the latter's second expedition
5 During the last decades, although traditional artifacts are still being used during ceremonies, sometimes borrowed from other Bororo villages, the Bororo are engaged in producing non-traditional artifacts in order to make money and buy goods in Brazilian cities. 
to the Upper Xingu and Bororo Indians and stayed on to visit the indigenous population along the Purus and Araguaia rivers; Herrmann Meyer (1826-1909), who visited the Upper Xingu area in 1896 and 1899 accompanied by Karl Ranke (1870-1926) and Theodor Koch-Crünberg (1872-1924) (Schaden, 1993: 111); Fritz Krause (1881-1963), who besides studying the material culture of the Upper Xingu Indians visited the Karajá of the Araguaia river and the Kayapó in 1908 and published ethnographic data on the Upper Xingu and the Karajá (Baldus 1954: 14); and Max Schmidt (1874-1950) visiting the Upper Xingu area four times from 1900 onwards. Later research was conducted, for example, by Gerhard Baer (1934-2017), Mark Münzel (b.1943), Günther Hartmann (1924-2012), and Rolf Krusche (b.1938).

In other Brazilian regions, the German tradition was continued by Herbert Baldus (1899-1970), who migrated to Brazil in order to escape the Nazi regime and did important research among the Tapirapé and several other Brazilian Indian tribes; Curt Nimuendajú (1883-1945), who worked among Gê-and Tupi-speaking Indians producing an ethnographic map and publishing many articles and books; and Egon Schaden (1913-1991), son of a Cerman immigrant who published important studies on Tupi-speaking Guarani and several other indigenous tribes. According to Schaden, German tradition consisted of obtaining solid empirical data that, more than illustrating theories, are gathered to prove them.

The work of Karl von den Steinen may be considered the beginnings of systematic ethnological fieldwork, and goes on inspiring new research among Brazilian Indigenous tribes.

I want to thank Dr. Han Vermeulen for encouraging me to write this article and Dr. Michael Kraus for his valuable comments

Renate Brigitte Viertler was born in Cermany, and lives in Brazil where she did her studies in social sciences at the University of São Paulo. Starting as a teacher at the Anthropology Department of the same university, she engaged in ethnological fieldwork among the Bororo Indians of Mato Crosso. Obtaining her PhD in 1973 and becoming Associate Professor, she published books and articles on Bororo social organization besides lecturing and teaching at foreign universities. The last few years she spent studying the theoretical foundations of Cerman ethnology and anthropology. Her latest book Os Fundamentos da Teoria Antropológica Alemã: Etnologia e Antropologia em Países de Língua Alemã (1700-1950) was published in São Paulo by Editora Annablume in April 2018. 


\section{BIBLIOGRAPHY}

BALDUS, Herbert

1954 Bibliografia crítica da etnologia brasileira, vol. I. Comissão do IV Centenário da Cidade de São Paulo. São Paulo, Serviço de Comemorações Culturais. Reprint: Nendeln/Liechtenstein, Kraus reprinted 1970.

BROGIATO, Heinz Peter

2005 "Karl von den Steinen". In ADAM, Thomas (org.). Germany and the Americas: Culture, Politics and History. Santa Barbara, ABC-CLIO.

COELHO, Vera Penteado (org.)

1993 Karl von den Steinen: um século de antropologia no Xingu. São

Paulo, Editora da Universidade de São Paulo/FAPESP.

HARTMANN, Günther

1993 "As coleções de Karl von den Steinen no Museu Etnológico de Berlim". In COELHO, Vera Penteado (org.) Karl von den Steinen: um século de antropologia no Xingu. São Paulo, Editora da Universidade de São Paulo/FAPESP, pp. 155-178.

HARTMANN, Thekla

1975 A contribuição da iconografia para o conhecimento de índios brasileiros do século XIX. São Paulo, Edição do Fundo de Pesquisas do Musseu Paulista da Universidade de São Paulo, Coleção Museu Paulista (Série de Etnologia, vol. 1).

KOEPPING, Klaus-Peter

1983 AdolfBastian and the Psychic Unity of Mankind: The Foundations of Anthropology in Nineteenth-Century Cermany. St. Lucia, University of Queensland Press. Revised edition: Münster/ Hamburg/London, LIT Verlag, 2000, reprinted 2005.

NOVAES, Sylvia Caiuby

2006 Etnografia e imagem. São Paulo, Departamento de Antropologia, Faculdade de Filosofia, Letras e Ciências Humanas, Universidade de São Paulo. 
PETSCHELIES, Erik

2018 "Karl von den Steinen's Ethnography in the Context of the Brazilian

Empire". Sociologia e Antropologia, Rio de Janeiro, 8 (2): 543-569.

SCHADEN, Egon

1956 "Karl von den Steinen e a exploração científica do Brasil".

Revista de Antropologia, São Paulo, 4 (2): 117-128.

1977 "As origens da imagem científica do índio". O Estado de São Paulo, 6 fev. Suplemento Cultural.

1993 "Pioneiros alemães da exploração etnológica do Alto

Xingu." In COELHO, Vera Penteado (org.) Karl von den Steinen:

um século de antropologia no Xingu. São Paulo, Editora da

Universidade de São Paulo/FAPESP, pp. 111-129.

\section{SCHEFOLD-VON DEN STEINEN, Marianne}

1993 "Síntese biográfica de Karl von den Steinen". In COELHO, Vera Penteado (org.) Karl von den Steinen: um século de antropologia no Xingu. São Paulo, Editora da Universidade de São Paulo/FAPESP, pp. 19-28.

STEINEN, Karl von den

1886 Durch Central Brasilien. Expedition zur Erforschung des Schingú im ]ahre 1884 [Through Central Brazil: An Expedition to Study the Xingu in 1884]. Leipzig, F.A. Brockhaus. Reprint: Fines Mundi, Saarbrücken, 2006. Portuguese translation, 1942.

1887 a "O Rio Xingu". Revista da Sociedade de Ceographia do Rio de Janeiro, tomo III, Boletim 1: 95-106.

1887b "O Rio Xingu." Revista da Sociedade de Ceographia do Rio de Janeiro, tomo IV, Boletim 3, pp. 189-212.

1889 Erfahrungen zur Entwicklungsgeschichte des Völkergedankens [Experiences regarding the Developmental History of the Thinking of Peoples]. Berlin, unpublished habilitation thesis, University of Berlin.

1892 Die Bakaïrí-Sprache: Wörterverzeichnis, Sätze, Sagen, Grammatik. Mit Beiträgen zu einer Lautlehre der karaibischen Crundsprache [The Bakairi Language: Vocabulary, Sentences, Legends, Crammar. With Contributions to a Phonetics of the Carib Basic Language]. Leipzig, K.F. Koehler's Antiquarium. 
1894 Unter Naturvölkern Zentral-Brasiliens. Reiseschilderung und Ergebnisse der zweiten Schingú-Expedition 1887-1888 [Among Peoples of Nature in Central Brazil: Travelogue and Results from the Second Xingu Expedition, 1887-1888]. Berlin, Geographische Verlagsbuchhandlung von Dietrich Reimer. Reprint: Fines Mundi, Saarbrücken 2006.

1905 "Cedächtnisrede auf Adolf Bastian". Zeitschrift für Ethnologie, 37: 236-249.

1925-28 Die Marquesaner und ihre Kunst: Studien über die Entwicklung primitiver Südseeornamentik nach eigenen Reiseergebnissen und dem Material der Museen. 3 vols. Berlin, Dietrich Reimer. Reprint: New York, 1969; Fines Mundi, Saarbrücken, 2006.

1940 "Entre os aborígenes do Brasil Central". Revista do Arquivo Municipal, São Paulo, XXXIV-LVIII. Tradução de Egon Schaden e introdução de Herbert Baldus.

1942 O Brasil Central. São Paulo, Companhia Editora Nacional (Brasiliana, Grande Formato, vol. III).

STEINEN, Ulrich von den

2010 Expeditionsreisen am Amazonas. Der Ethnologe Karl von den Steinen (1855-1929). Wien/Weimar/ Köln, Böhlau Verlag.

THIEME, Inge

1993 "Karl von den Steinen: vida e obra". In COELHO, Vera Penteado (org.) Karl von den Steinen: um século de antropologia no Xingu. São Paulo, Editora da Universidade de São Paulo/FAPESP, pp. 37-108.

VERMEULEN, Han F.

2015 Before Boas: The Genesis of Ethnography and Ethnology in the German Enlightenment. Lincoln and London, NE, University of Nebraska Press (Critical Studies in the History of Anthropology).

2016 "The Origins of Ethnography". Weblog, posted by the University of Nebraska Press in Guest blogs, October 18, 2016.

VIERTLER, Renate Brigitte

1976 As aldeias bororo. Alguns aspectos de sua organização social. São Paulo, Edição Fundo de Pesquisas do Museu Paulista da Universidade de São Paulo, Coleção Museu Paulista, Série de Etnologia, vol. 2.

1991 A refeição das almas. Uma interpretação etnológica do funeral dos índios Bororo-Mato Crosso. São Paulo, Editora Hucitec, Editora da Universidade de São Paulo. 
1993 "Karl von den Steinen e o estudo antropológico dos bororos".

In COELHO, Vera Penteado (org.) Karl von den Steinen:

um século de antropologia no Xingu. São Paulo, Editora da

Universidade de São Paulo/FAPESP, pp. 183-221.

2018 Os fundamentos da teoria antropológica alemã: etnologia e antropologia em países de língua alemã: 1700-1950. [The Foundations of

German Anthropological Theory: Ethnology and Anthropology

from 1700 to 1950] São Paulo, Editora Annablume.

Received on August 9, 2018. Accepted on December 14, 2018. 